\title{
An Approach to Evaluate Program Outcomes and Program Educational Objectives through Direct and Indirect Assessment Tools
}

\author{
https://doi.org/10.3991/ijet.v14i23.11018 \\ Akash Rajak ${ }^{(\varpi)}$, Ajay Kumar Shrivastava, Arun Kumar Tripathi \\ KIET Group of Institutions, Ghaziabad, India \\ akashrajak@gmail.com
}

\begin{abstract}
The model of outcome-based education is based on achieving attainments at the end of each course by the students in any undergraduate or postgraduate program. It was implemented in all technical institutions of India as per the guidelines of All India Council for Technical Education, India. The attainments are calculated by deploying some direct and indirect tools. This include courses results, placements, projects and various surveys like alumni, employer etc. The paper discusses the attainment of Program Educational Objectives and Program Outcomes for any undergraduate or postgraduate program. In outcome-based education, certain targets are to be set on the basis of previous year performance of students and these targets are achieved in the form of attainments. In this research, a comparative study of last three batches of a postgraduate course is done in the form of attainments.
\end{abstract}

Keywords - outcome-based education, course outcome, program outcome, program educational objectives

\section{Introduction}

The outcome-based education is based on the assessment of students through attainments on the basis of certain defined targets. The model can be implemented on any undergraduate or postgraduate course. The faculty members are acting as a facilitator and mentor to the students for achieving the targets. The assessments are evaluated in form of attainments of Program Educational Objectives (PEO) and Program Outcomes (PO).

The model begins with formulating Vision and Mission of the department in aligns with Vision and Mission of Institute. The PEO and PO of a program are defined in accordance to Vision and Mission of the department and as per twelve National Board of Accreditation (NBA) graduate attributes. The PEO are borderer statements defining the objectives of any undergraduate or postgraduate program. Now as per the university curriculum we have to define different course outcomes for each course or subjects. The courses include theory subjects, practical subjects and projects. Similarly, we have to define course outcomes for various surveys like alumni survey, curriculum 
survey, exit survey etc. The course outcomes are written in the form of statements describing the outcome of a particular course. A mapping of Course Outcome and Program Outcome is established with strong, medium and weak correlations. The target for each course can be set, which has to be attained. The target can be set on the basis of result of previous years. i.e. the performance of various batches of graduated students.

The Vision, Mission, PEO and PO are then approved by stakeholders like management, alumni, industry persons and Board of Studies (BoS) before implementation. It can be discussed and communicated to the students or learners.

A systematic process is followed for finding the attainments of each course including surveys. The Attained value of Program Educational Objectives and Program Outcomes are calculated. A gap analysis is performed to check the attainment against targets, if it is not achieved then gaps are identified. The gaps are fill by redefining targets, revising Course Outcome, conducting remedial classes for the weak students or by giving extra assignments to the students in the same academic year or consecutive year.

\section{Background}

In the review study the authors stated that outcome-based education is widely practiced by educational institutions from primary schooling to degree level. The outcome-based education is helpful to both educators and learners. It can be used in the designing of curriculum [1]. Vivek [2] discussed how the poor practices of current educational system can be overcome by outcome-based education. The Course Outcome is designed for a subject and minimum target is to be set. If a student attains that target then only that course is completed. A gap analysis is to be performed at the end of each course to check whether targets are achieved or not. Jayashree [3] expressed the fact that the curriculum must be measured in terms of outcomes and at the end of each course students has to achieve the outcomes. The curriculum may be designed in way to meet the challenges of industry to make the students more market ready. Subbraman et al. [4] distributed the contribution of course study as $80 \%$ and graduate exit survey as $20 \%$ for the attainment of Program Outcomes. In the attainment of Program Outcomes an additional weight factor is associated as per AICTE curriculum model. Aziza et al. [5] evaluated the effectiveness of learning outcomes from student's perspectives. The results show that learning outcomes is to be reviewed. As a result of this curriculum is redesigned by introducing new courses and changing teaching approach from surface to deep learning. Oriahand et al. [6] studied the performance of students in some course and find that there is significant difference in outcome-based education and non-outcome-based education learning. The outcome-based education mean grade point average is higher than non-outcome-based education. Rajak et al. [7] discussed the process for the attainment of Program Educational Objectives for post graduate courses. A comparative study of attainments was made for different batches. The outcome-based education starts from defining Vision and Mission to the department to the attainment of PO and PEO [8]. The assessment process is used to 
calculate the attainments of course and Program Outcomes. These attainments can be used to find how much the assessment process fulfills the criteria of accreditation body [9]. Marks et al. [10] discussed how the course evaluation can be used to improve academic programs. They conducted a study based on 23 academic programs. Uziak et al. [11] highlighted about problem-based learning, which is an effective tool in primary and secondary education. It can also be used in degree level courses. They implemented it on mechanics course of mechanical engineering.

\section{$3 \quad$ Direct and Indirect Assessment Tools}

The attainments are calculated by deploying direct and indirect assessment tools. The direct tool comprises of class tests, assignments, tutorials, projects, placements etc. The indirect tools include various surveys like exit survey, alumni survey, employer survey, curriculum feedback etc. In the process of calculating the attainments the outcomes of these tools are designed by writing the outcomes in few statements. These are known as Course Outcomes. The department may run different programs but program outcome for each program has to be separately designed. The PO are based on twelve NBA graduate attributes. There can be separate Program Outcomes for engineering and management programs.

The mapping of Course Outcome and Program Outcome is established in matrix form having 3 (strong), 2 (moderate) and 1 (weak) correlations as shown in Table 1. The empty cells in CO-PO mapping shows no correlation. The Program Outcomes are attained through direct and indirect tools. The different assessment tools are shown in Figure 1.

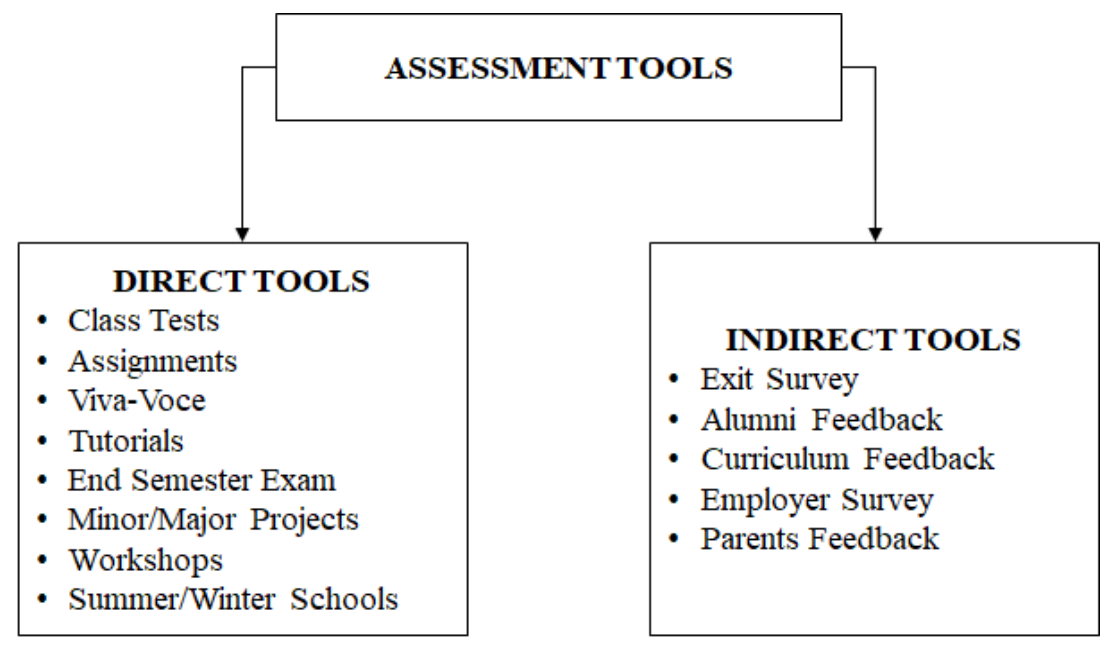

Fig. 1. Direct and Indirect assessment tools used in the attainment process 


\subsection{Direct tools}

The direct tools are the assessment techniques related to the performance of students in different examinations. These examinations include class tests, assignments, practical, projects and performance in end semester examination. The direct tools also include placement data. A weightage to results, project and placement is to be given for calculating attainments. In our research we gave 50 percent to result and 25 percent each to project and placement.

Internal and External Exam assessments of a course is carried using class tests and end semester examinations. The students are also given regular assignments and they have to submit these assignments from time to time, which are properly evaluated by the subject teacher. The assessment of a course is based on the attainment of Course Outcomes and external average in university exam. The Course Outcomes of DSARCS406 and its mapping with Program Outcomes is given in Table 1 and 2 respectively. The Course Outcome may be defined unit wise or on the basis of delivery of contents set by the teacher. Here the Course Outcome of DSA-RCS406 is defined as unit wise and the course has five units.

Table 1. Course Outcomes of DSA-RCS406

\begin{tabular}{|l|l|}
\hline Course Outcome & \multicolumn{1}{c|}{\begin{tabular}{c}
\multicolumn{1}{c|}{ Description } \\
Student will able to understand:
\end{tabular}} \\
\hline $\mathrm{CO} 1$ & $\begin{array}{l}\text { The fundamental concept of data structures, algorithms and will be familiar with re- } \\
\text { cursive functions. }\end{array}$ \\
\hline $\mathrm{CO} 2$ & The concept of linked list data structure and implementation of stack, queue etc. \\
\hline $\mathrm{CO} 3$ & The non-linear data structures like tree and graph. \\
\hline $\mathrm{CO} 4$ & The complexities and implementation of sorting and searching algorithms. \\
\hline CO5 & The various graph algorithms such as shortest path and minimum spanning tree. \\
\hline
\end{tabular}

Table 2. CO-PO mapping of DSA-RCS406 course

\begin{tabular}{|l|c|c|c|c|c|c|c|c|c|c|c|c|}
\hline \multirow{4}{*}{$\begin{array}{c}\text { Course } \\
\text { Outcome }\end{array}$} & \multicolumn{10}{|c|}{ Program Outcome } \\
\hline & 1 & 2 & 3 & 4 & 5 & 6 & 7 & 8 & 9 & 10 & 11 & 12 \\
\hline $\mathrm{CO} 1$ & 3 & 3 & & 1 & & & & & & & & 1 \\
\hline $\mathrm{CO} 2$ & 3 & 2 & & 2 & & & & & & & & 1 \\
\hline $\mathrm{CO} 3$ & 3 & 2 & & 1 & & & & & & & & 2 \\
\hline $\mathrm{CO} 4$ & 3 & 2 & & 1 & & & & & & & & 2 \\
\hline $\mathrm{CO} 5$ & 3 & 2 & & 2 & & & & & & & & 2 \\
\hline
\end{tabular}

Projects Evaluation are the assessment of projects which the students have developed during the tenure of their degree. The projects are evaluated and the project assessment is included in calculation of attainments. The evaluation is based on quality of project, technology used, project presentations and its documentation.

Placement Records are also included in calculating attainments. The placement assessment is based on percentage of placement of a particular batch and average package of students. 


\subsection{Indirect tools}

The other tools used in the attainment process are indirect tools. The indirect tools include surveys from different stakeholders like graduated students, industry, parents etc. The survey can be carried out online or offline by filling feedback forms. A good sample size can be taken from surveys and can be used in attainment process.

Alumni Survey is conducted through alumni members of a particular batch. All the alumni who have graduated from the institute are requested to give feedback. This feedback can be used by the Institute for reviewing the academic process so as to enhance the quality of imparted education and as well as in the attainment process.

Exit Survey is conducted through final year students to access their understanding, knowledge gained and applicability by learning the program. The questionnaire can be based on student's analysis towards analysis of complex engineering problems, designing of solutions for complex engineering problems, able to apply reasoning within the contextual knowledge, can able to apply ethical principles and commitment to professional ethics and responsibilities.

Curriculum Feedback is also conducted through final year students to get feedback on university designed curriculum. The questionnaire can be related to design of syllabus, coverage of advance topics, contents of syllabus are industry oriented, learning value (in terms of skills, concepts, knowledge, analytical abilities, or broadening perspectives), its applicability in real life etc. The Course Outcome of curriculum feedback and its mapping with Program Outcome is shown in Table 3 and 4 respectively.

Table 3. Course Outcomes of curriculum feedback

\begin{tabular}{|l|l|}
\hline $\begin{array}{c}\text { Course } \\
\text { Outcome }\end{array}$ & \\
\hline CO1 & The syllabus is suitable to the course. \\
\hline CO2 & The aims and objectives of the syllabi are well defined and clear to teachers and students. \\
\hline CO3 & The course content is followed by corresponding reference materials. \\
\hline CO4 & The syllabus has good balance between theory and application. \\
\hline CO5 & The syllabus has made me interested in the subject area. \\
\hline CO6 & It covers modern and advanced topics. \\
\hline CO7 & The syllabus is industry oriented. \\
\hline CO8 & The syllabus has learning values in terms of skills, concepts, knowledge, analytical abilities etc. \\
\hline CO9 & It has applicability in real life. \\
\hline CO10 & It helps for going to higher studies. \\
\hline
\end{tabular}

Table 4. Mapping of curriculum feedback with Program Outcomes

\begin{tabular}{|l|c|c|c|c|c|c|c|c|c|c|c|c|}
\hline \multicolumn{1}{|c|}{ Course Outcome } & \multicolumn{10}{|c|}{ Program Outcome } \\
\cline { 2 - 13 } & 1 & 2 & 3 & 4 & 5 & 6 & 7 & 8 & 9 & 10 & 11 & 12 \\
\hline $\mathrm{CO} 1$ & & & & & & & & 2 & 3 & & & \\
\hline $\mathrm{CO} 2$ & & & & & & & & & & & & \\
\hline $\mathrm{CO} 3$ & & & & & & & & & & & & \\
\hline $\mathrm{CO} 4$ & & 3 & 1 & & 3 & & & & & & & \\
\hline $\mathrm{CO} 5$ & & & & & & & & & & & & \\
\hline
\end{tabular}




\begin{tabular}{|l|l|l|l|l|l|l|l|l|l|l|l|l|}
\hline CO6 & & & & & 3 & & 3 & 2 & & & & \\
\hline CO7 & & & & 3 & & & & & & & 2 & \\
\hline CO8 & & 2 & 1 & & & & & & & 1 & 2 & \\
\hline CO9 & & & 2 & & 3 & & & & & & & \\
\hline CO10 & & & & & & 1 & & & & 2 & \\
\hline
\end{tabular}

Employer Feedback is collected from the industry where the graduated student is working. The feedback is accessed on different parameters. The parameters can be its level of adherence to personal and professional ethics whilst working on engineering problems, its ability to provide solutions in engineering problems individually and as a member of the team, has ability to communicate effectively both verbal as well as written etc.

\section{Tools, Criteria and Frequency of Assessment Tools}

The assessment process for calculating attainments utilizes direct and indirect tools. The Table 5 demonstrates the direct and indirect tools used in the assessment process for the achievement of PO and PEO. The assessment tools have certain criteria for evaluation and each tool has certain period when the evaluation is done.

Table 5. Direct and indirect tools of assessment process

\begin{tabular}{|l|l|l|l|}
\hline $\begin{array}{c}\text { Type of As- } \\
\text { sessment Tool }\end{array}$ & Assessment Tool & \multicolumn{1}{|c|}{ Assessment Criteria } & $\begin{array}{c}\text { Data Collection } \\
\text { Frequency }\end{array}$ \\
\hline \multirow{5}{*}{ Direct } & $\begin{array}{l}\text { Internal and Exter- } \\
\text { nal Marks }\end{array}$ & Pass percentage, external average. & $\begin{array}{l}\text { Once every } \\
\text { semester }\end{array}$ \\
\cline { 2 - 4 } & Project Evaluation & Quality of projects \& Technologies used. & $\begin{array}{l}\text { Once every } \\
\text { semester }\end{array}$ \\
\cline { 2 - 4 } & Placement Records & Number of students placed, quality and package. & Once every year \\
\hline \multirow{5}{*}{ Indirect } & Alumni Survey & $\begin{array}{l}\text { Level of achievement in project management, profes- } \\
\text { sional \& ethical responsibility, communication, lead- } \\
\text { ership and entrepreneur. }\end{array}$ & Once every year \\
\cline { 2 - 4 } & Exit Survey & $\begin{array}{l}\text { Use technologies, professional ethics, lifelong learn- } \\
\text { ing etc. }\end{array}$ & Once every year \\
\cline { 2 - 4 } & $\begin{array}{l}\text { Curriculum Feed- } \\
\text { back }\end{array}$ & $\begin{array}{l}\text { Well defined syllabus, advance topics, industry ori- } \\
\text { ented and applicability in real life. }\end{array}$ & Once every year \\
\cline { 2 - 4 } & Employer Survey & $\begin{array}{l}\text { Employee is able to work in multidisciplinary envi- } \\
\text { ronment, leadership qualities, team work etc. }\end{array}$ & Once every year \\
\hline
\end{tabular}

In final attainments equal weightage is given to direct and indirect tools. The procedure for calculating the attainments is discussed in next section.

\section{$5 \quad$ Attainment Process}

The attainment process begins from formulation of Vision and Mission of the department along with defining PEO and PO of a postgraduate or undergraduate program. The Course Outcomes are defined for different subjects including surveys and 
are mapped with Program Outcomes. The direct attainments of various courses are calculated based on the performance of students in internal and external examinations. Similarly, surveys from alumni, employer etc. are conducted and the indirect attainments are calculated. The Expected and Attained value is calculated from direct and indirect tools.

Further, the Expected and Attained Program Outcomes are calculated from Course Outcomes. In PO calculation equal weightage is given to direct and indirect tools. The PEO are mapped with PO and average of mapped PO gives Expected and Attained PEO.

The PO and PEO attainments of last three passed out batches are calculated along with finding gap in case of deviation for very low or very high attainments [12].

The different formulas used in the calculation of attainments are as follows:

Expected $P O=$ Average $($ Course Outcomes Colum wise in CO - PO Matrix $)(1)$

The Attained PO is based on the assessment of internal and external exam of each course by calculating Net_CO attainment. In Net_CO calculation 30\% weightage is given to Internal Exam and $70 \%$ weightage is given to External Exams.

$$
\begin{aligned}
& \text { Net_CO }= \\
& 0.3 *(\text { Avgerage of Internal } C O)+0.7 *(\text { CO attainment in External Exam })(2) \\
& \text { Attained } P O=\frac{\text { Expected } P O * N_{\text {Net_CO }}}{3}
\end{aligned}
$$

In final attainments of PEO and PO equal weightage is given to direct and indirect tools.

$$
\begin{gathered}
\text { PO Attainment }=0.5 * \text { Direct Tools }+0.5 * \text { Indirect Tools } \\
\text { Direct Tools }=0.5 * \text { Results }+0.25 * \text { Placements }+0.25 \text { Projects } \\
\text { Indirect Tools }=0.25 * \text { Alumni Survey }+0.25 * \text { Exit Survey }+0.25 * \\
\text { Employer Survey }+0.25 * \text { Curriculum Feedback }
\end{gathered}
$$

The PEO are calculated by taking average of mapped Program Outcomes. For example, in case of PEO1 it is calculated as

$$
P E O 1=\frac{(P 01+P O 2+P 03+P O 5)}{4}
$$

\section{$6 \quad$ Results and Discussion}

The data of 2018 graduated students are given in this section. The results of different students for all semester examinations are recorded and the Expected and Attained value is calculated for each subject including projects, placements and surveys. From Equation 1, the average of CO-PO mapping gives Expected PO. 
In Table 5 the Expected PO attainment for different subjects is given. In Table 6 the Attained PO is given and it depends on student's performance in internal and external exams including assignments and quizzes. The Attained PO is calculated from equation 2 and 3.

Table 6. Expected PO attainment for different subjects

\begin{tabular}{|l|c|c|c|c|c|c|c|c|c|c|c|c|}
\hline \multicolumn{1}{|c|}{ Subject } & PO1 & PO2 & PO3 & PO4 & PO5 & PO6 & PO7 & PO8 & PO9 & PO 10 & PO 11 & PO 12 \\
\hline Course-1 & 1.00 & 1.60 & 1.20 & 1.80 & 1.20 & 1.00 & 2.40 & 1.00 & 2.80 & 1.20 & 2.60 & 2.80 \\
\hline Course-2 & 2 & 2 & 1.5 & 2 & 1.33 & & & & & 1 & & \\
\hline Course-N & 3.00 & 2.33 & & 3.00 & 2.00 & 2.50 & 2.67 & & 2.67 & & 2.67 & \\
\hline Average & 2.18 & 2.28 & 2.12 & 2.26 & 1.82 & 1.61 & 1.93 & 1.71 & 1.84 & 1.66 & 1.97 & 2.18 \\
\hline
\end{tabular}

Table 7. Attained PO for different subjects

\begin{tabular}{|l|c|c|c|c|c|c|c|c|c|c|c|c|}
\hline \multicolumn{1}{|c|}{ Subject } & $\begin{array}{c}\text { PO } \\
\mathbf{1}\end{array}$ & PO2 & PO3 & PO4 & PO5 & PO6 & PO7 & PO8 & PO9 & PO 10 & PO 11 & PO 12 \\
\hline Course-1 & $\begin{array}{c}0.5 \\
3\end{array}$ & 0.85 & 0.64 & 0.96 & 0.64 & 0.53 & 1.28 & 0.53 & 1.49 & 0.64 & 1.39 & 1.49 \\
\hline Course-2 & $\begin{array}{c}1.3 \\
3\end{array}$ & 1.33 & 1.00 & 1.33 & 0.89 & 0.00 & 0.00 & 0.00 & 0.00 & 0.67 & 0.00 & 0.00 \\
\hline Course-N & $\begin{array}{c}3.0 \\
0\end{array}$ & 2.33 & & 3.00 & 2.00 & 2.50 & 2.67 & & 2.67 & & 2.67 & \\
\hline Average & $\begin{array}{c}1.2 \\
3\end{array}$ & 1.28 & 1.11 & 1.23 & 1.02 & 0.85 & 0.99 & 0.86 & 0.99 & 0.84 & 1.06 & 1.13 \\
\hline
\end{tabular}

In case of surveys the Attained PO depends on the feedback of stake holders. The feedbacks can be collected online or offline. The Expected PO and Attained PO are calculated for different surveys. The curriculum feedback is shown in Table 8.

Table 8. Curriculum Feedback of $\mathrm{n}$ graduated students

\begin{tabular}{|l|c|c|c|c|c|c|c|c|c|c|}
\hline Student Name & CO1 & CO2 & CO3 & CO4 & CO5 & CO6 & CO7 & CO8 & CO9 & CO 10 \\
\hline Student-1 & 4 & 1 & 4 & 5 & 5 & 3 & 5 & 5 & 4 & 5 \\
\hline Student-2 & 2 & 5 & 3 & 5 & 3 & 2 & 5 & 3 & 5 & 2 \\
\hline Student-N & 5 & 5 & 5 & 5 & 5 & 5 & 2 & 5 & 5 & 1 \\
\hline Average & 4.53 & 4.82 & 4.65 & 4.53 & 4.47 & 4.24 & 4.12 & 4.65 & 4.59 & 4.65 \\
\hline Overall Average \\
\hline \multicolumn{19}{|l|}{} \\
\hline \multicolumn{19}{|l|}{ Normalized (Scale 3) } & \multicolumn{10}{|c|}{4.52} \\
\hline
\end{tabular}

The Expected and Attained PO for curriculum feedback is given in Table 9.

Table 9. Expected and Attained PO of Curriculum Feedback

\begin{tabular}{|l|l|l|l|l|l|l|l|l|l|l|l|l|}
\hline \multicolumn{1}{|c|}{ Type } & PO1 & PO2 & PO3 & PO4 & PO5 & PO6 & PO7 & PO8 & PO9 & PO10 & PO11 & PO12 \\
\hline Expected & & 2.5 & 1.33 & 3 & 3 & & 2 & 2 & 3 & 1 & 2 & \\
\hline Attained & & 2.03 & 1.08 & 2.44 & 2.44 & & 1.63 & 1.63 & 2.44 & 0.81 & 1.63 & \\
\hline
\end{tabular}


The Final Expected and Attained PO is calculated from direct and indirect tools through equations 4, 5 and 6. The final PO attainment for last three batches is given in Table 9. The Expected PO value for different batches varies due to elective subjects.

Table 10.

The final PO attainments for last three batches of postgraduate course

\begin{tabular}{|l|c|c|c|c|c|c|}
\hline \multirow{2}{*}{$\begin{array}{c}\text { Program } \\
\text { Outcome }\end{array}$} & \multicolumn{2}{|c|}{ 2015-18 } & \multicolumn{2}{c|}{ 2014-17 } & \multicolumn{2}{c|}{ 2013-16 } \\
\cline { 2 - 7 } & Expected & Attained & Expected & Attained & Expected & Attained \\
\hline PO1 & 2.06 & 1.68 & 2.04 & 1.68 & 2.05 & 1.57 \\
\hline PO2 & 2.19 & 1.73 & 2.18 & 1.69 & 2.19 & 1.63 \\
\hline PO3 & 2.28 & 1.85 & 2.28 & 1.84 & 2.30 & 1.79 \\
\hline PO4 & 1.83 & 1.39 & 1.80 & 1.34 & 1.82 & 1.34 \\
\hline PO5 & 2.22 & 1.83 & 2.20 & 1.76 & 2.21 & 1.74 \\
\hline PO6 & 2.09 & 1.76 & 2.07 & 1.73 & 2.08 & 1.66 \\
\hline PO7 & 1.94 & 1.53 & 1.92 & 1.51 & 1.93 & 1.44 \\
\hline PO8 & 2.08 & 1.70 & 2.09 & 1.67 & 2.11 & 1.64 \\
\hline PO9 & 2.48 & 2.05 & 2.51 & 2.00 & 2.52 & 1.95 \\
\hline PO10 & 1.96 & 1.63 & 1.96 & 1.61 & 1.97 & 1.57 \\
\hline PO11 & 2.20 & 1.81 & 2.19 & 1.78 & 2.19 & 1.72 \\
\hline PO12 & 1.71 & 1.32 & 1.69 & 1.35 & 1.68 & 1.24 \\
\hline
\end{tabular}

The PEO attainment is calculated from equation 7. The PEO attainment for the last three batches of postgraduate course is given in Table 11.

Table 11. The PEO attainment for last three batches of postgraduate course

\begin{tabular}{|l|c|c|c|}
\hline \multirow{2}{*}{ Program Outcome } & \multicolumn{3}{|c|}{ \% Attainment } \\
\cline { 2 - 4 } & $\mathbf{2 0 1 5 - 1 8}$ & $\mathbf{2 0 1 4 - 1 7}$ & $\mathbf{2 0 1 3 - 1 6}$ \\
\hline PO1 & 81.22 & 82.19 & 76.48 \\
\hline PO2 & 78.97 & 77.59 & 74.60 \\
\hline PO3 & 81.42 & 80.63 & 78.04 \\
\hline PO4 & 76.04 & 74.66 & 73.43 \\
\hline PO5 & 82.52 & 79.76 & 78.64 \\
\hline PO6 & 84.36 & 83.80 & 80.16 \\
\hline PO7 & 79.05 & 78.53 & 74.80 \\
\hline PO8 & 81.71 & 79.90 & 77.87 \\
\hline PO9 & 82.81 & 79.65 & 77.62 \\
\hline PO10 & 83.13 & 82.08 & 79.91 \\
\hline PO11 & 82.38 & 81.01 & 78.71 \\
\hline PO12 & 77.10 & 79.81 & 73.98 \\
\hline
\end{tabular}




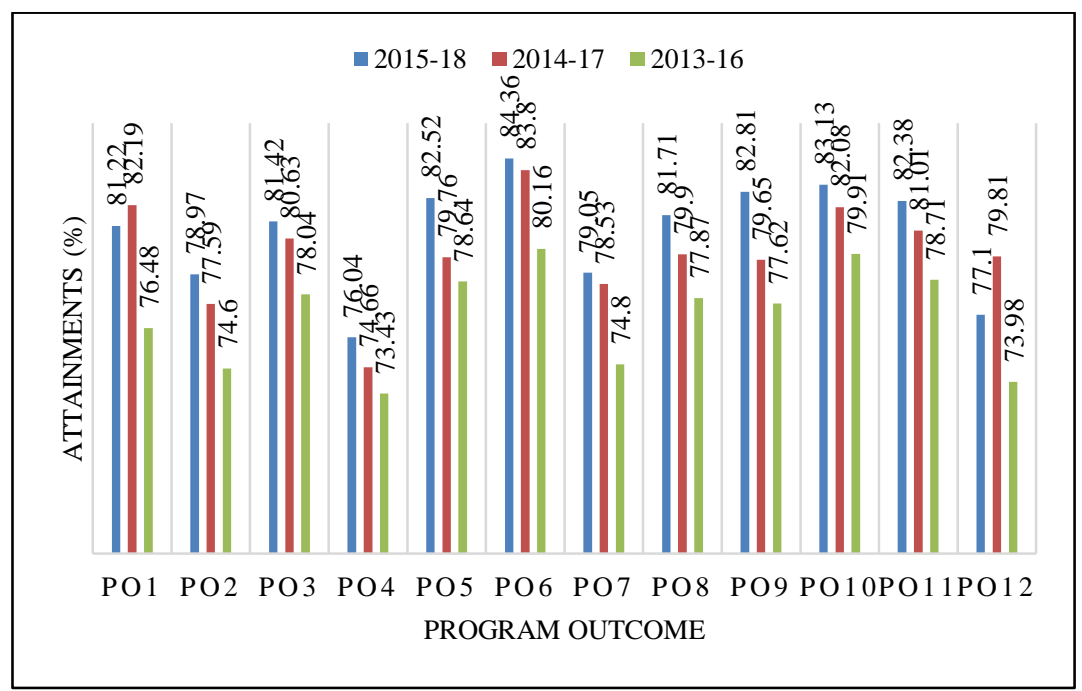

Fig. 2. PO attainments for different batches of postgraduate program

The Figure 2 gives percentage of final PO attainment for last three batches. The attainment level of all Program Outcomes is good. In case if there is very high attainment, very low attainment or poor attainment from last year's then there is a need for gap analysis. The gap analysis will tell the reason for the non-attainments or very high attainments. This gap analysis will be discussed in department BoS meeting along with the stakeholders. A corrective action plan is to be taken to reduce the gap.

The Table 11 shows a mapping between PEO and PO. The PEO are calculated from equation 7. The PEO attainment is given in Table 12 and the percentage of PEO attainment is given in Table 13.

Table 12.

The mapping of PEO with PO

\begin{tabular}{|l|l|}
\hline Program Educational Objectives & \multicolumn{1}{|c|}{ Mapped Program Outcomes } \\
\hline PEO1 & $\mathrm{PO} 1, \mathrm{PO} 2, \mathrm{PO} 3, \mathrm{PO} 5$ \\
\hline PEO2 & $\mathrm{PO} 1, \mathrm{PO} 2, \mathrm{PO} 5, \mathrm{PO} 6, \mathrm{PO} 7, \mathrm{PO} 9, \mathrm{PO} 10, \mathrm{PO} 11$ \\
\hline PEO3 & $\mathrm{PO}, \mathrm{PO} 4, \mathrm{PO} 6, \mathrm{PO} 10$ \\
\hline PEO4 & $\mathrm{PO}$, PO8, PO9, PO11 \\
\hline PEO5 & $\mathrm{PO}, \mathrm{PO} 10, \mathrm{PO} 11, \mathrm{PO} 12$ \\
\hline
\end{tabular}

Table 13.

The PEO Attainment for different batches

\begin{tabular}{|l|c|c|c|c|c|c|}
\hline \multirow{2}{*}{$\begin{array}{l}\text { Program Educa- } \\
\text { tional Objectives }\end{array}$} & \multicolumn{2}{|c|}{ 2015-18 } & \multicolumn{2}{c|}{ 2014-17 } & \multicolumn{2}{c|}{ 2013-16 } \\
\cline { 2 - 7 } & Expected & Attained & Expected & Attained & Expected & Attained \\
\hline PEO1 & 2.19 & 1.77 & 2.18 & 1.74 & 2.19 & 1.68 \\
\hline PEO2 & 2.14 & 1.75 & 2.13 & 1.72 & 2.14 & 1.66 \\
\hline PEO3 & 2.04 & 1.66 & 2.03 & 1.63 & 2.04 & 1.59 \\
\hline PEO4 & 2.24 & 1.85 & 2.25 & 1.80 & 2.26 & 1.76 \\
\hline PEO5 & 2.04 & 1.65 & 2.03 & 1.64 & 2.03 & 1.58 \\
\hline
\end{tabular}


Paper-An Approach to Evaluate Program Outcomes and Program Educational Objectives through..

Table 14.

The PEO attainment percentage for different batches

\begin{tabular}{|l|c|c|c|}
\hline \multirow{2}{*}{ Program Educational Objectives } & \multicolumn{3}{|c|}{ Attainment (\%) } \\
\cline { 2 - 4 } & $\mathbf{2 0 1 5 - 1 8}$ & $\mathbf{2 0 1 4 - 1 7}$ & $\mathbf{2 0 1 3 - 1 6}$ \\
\hline PEO1 & 81.04 & 80.02 & 76.97 \\
\hline PEO2 & 81.83 & 80.54 & 77.62 \\
\hline PEO3 & 81.38 & 80.46 & 78.00 \\
\hline PEO4 & 82.38 & 80.07 & 78.19 \\
\hline PEO5 & 81.18 & 80.91 & 77.84 \\
\hline
\end{tabular}

The comparative study of PEO attainment for the last three batches is given in Figure 3. The PEO value is gradually increasing from its previous value. In case of low attainments gap analysis is to be performed and is discussed in department BoS along with various stakeholders of program.

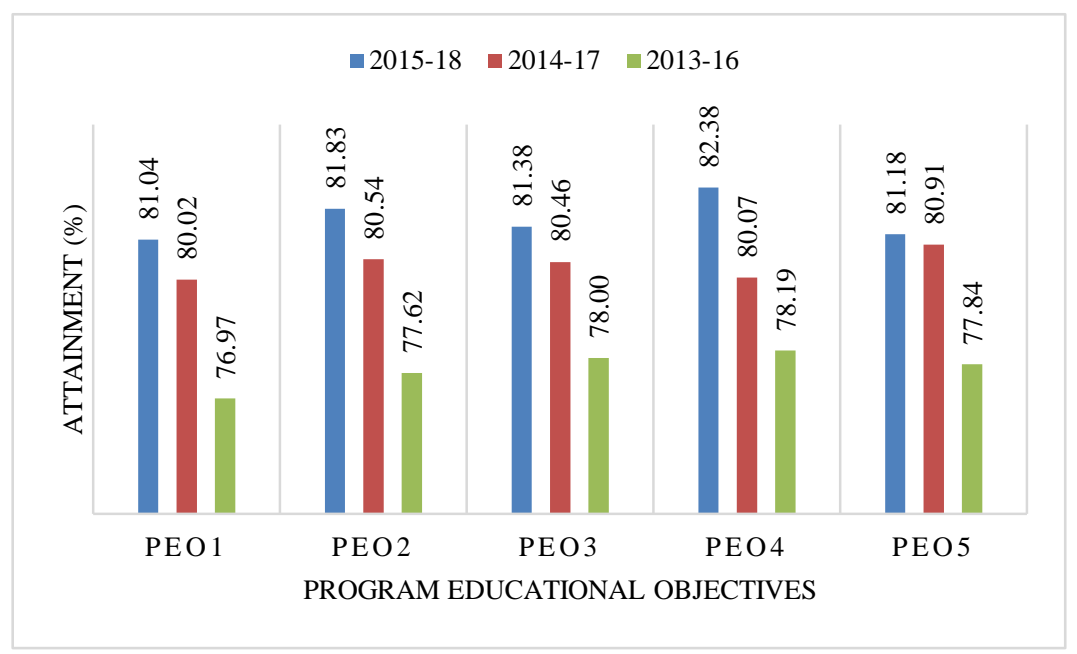

Fig. 3. PEO attainment for different batches of a postgraduate program

\section{$7 \quad$ Conclusion}

The outcome-based education is an innovative teaching learning methodology based on achieving targets. In this paper, we discussed about the direct and indirect tools used in the process of calculating attainments. We represented the complete attainment process starting from defining Vision, Mission, PEO and PO to final attainment of PO and PEO. The results from last three years of postgraduate course is presented. We also discussed how to find gap analysis in case of non-attainment of targets. The outcome-based learning is very helpful in validating the performance of students and helps in accreditation and assessment of program form various government bodies of India. 


\section{$8 \quad$ References}

[1] Hadi A.A, Zain N.M. (2016). Student's Perception towards Program Outcomes: A Systematic Review. International Journal of Education and Research, Vol. 4(3).

[2] Vivek C.M. (2017). Outcome Based Education-A Review. International Research Journal of Engineering and Technology, Vol. 4(7).

[3] Jayashree A. (2017). Moving towards an Outcome Based Education in Engineering. International Journal of Advanced Research in Computer Science, Vol. 8(8), pp. 587-591. DOI: http://dx.doi.org/10.26483/ijarcs.v8i8.4844

[4] Subbaraman S, Dharmadhikar V.B, Patil B.G. (2016). Computing Attainment of Program Outcomes by Associating Credit Based Weight Factor of the Components of Curriculum. Journal of Engineering Education Transformations. DOI: 10.16920/jeet/2016/v0i0/111632

[5] Aziza A.A, Yusofb K.M, Yatima J.M. (2012). Evaluation on the Effectiveness of Learning Outcomes from Students' Perspectives. International Conference on Teaching and Learning in Higher Education (ICTLHE 2012) in conjunction with RCEE \& RHED, 2012, pp. 22-30. DOI: 10.1016/j.sbspro.2012.09.628

[6] Oriahand A, Eng T. H, Senian M. (2012). Teaching and Learning Enhancement Through Outcome-Based Education Structure and Technology. e-Learning Support. Procedia-Social and Behavioural Sciences, 2012, pp. 87-92. DOI: https://doi.org/10.1016/j.sbspro.2012.09. $\underline{015}$

[7] Rajak A, Shrivastava A.K, Bhardwaj S, Tripathi A.K. (2019). Assessment and Attainment of Program Educational Objectives for Post Graduate Courses. International Journal of Modern Education and Computer Science, Vol. 11(2), pp. 26-32. https://doi.org/10.5815/ij $\underline{\text { mecs.2019.02.04 }}$

[8] Rajak A, Shrivastava A.K, Shrivastava D.P. (2018). Automating Outcome Based Education for the Attainment of Course and Program Outcomes. The Fifth HCT Information Technology Trends (ITT 2018), 2018, Dubai, UAE, pp. 373-376. DOI:_10.1109/CTIT. 2018.8649532

[9] Abdeljaber H.A.M, Ahmad S. (2017). Program Outcomes Assessment Method for MultiAcademic Accreditation Bodies: Computer Science Program as a Case Study. International Journal of Emerging Technologies in Learning, Vol. 12(5). DOI: https://doi.org/10.3991/ij et.v12i05.6410

[10] Marks A, AL-Ali M, Majdalawieh M, Bani-Hani A. (2017). Improving Academic Decision-Making through Course Evaluation Technology, International Journal of Emerging Technologies in Learning, Vol. 12(11). DOI: https://doi.org/10.3991/ijet.v12.i11.6987

[11] Uziak J, Kommula V.P. (2019). Application of Problem Based Learning in Mechanics of Machines Course. International Journal of Engineering Pedagogy, Vol. 9 (1). DOI: https:// doi.org/10.3991/ijep.v9i1.9673

[12] Rajak A, Shrivastava A.K, Shrivastava D.P. (2019). Course Outcome Attainments in OBE for Weak Students. International Journal of Innovative Technology and Exploring Engineering, Vol. 8(11). https://doi.org/10.35940/ijitee.k1421.0981119

\section{Authors}

Akash Rajak is working as Associate Professor in KIET Group of Institutions, Ghaziabad, India. He is having 17 years of teaching and research experience. He completed Ph.D. in Computer Science from Barkatullah University, Bhopal in the 
field of Temporal Data Mining. He did M.C.A from U.T.D Campus, Dr. H. S. Gour University, Sagar (M.P) in 2002. Dr. Rajak published various research papers in reputed journals and conferences. He served as program Co-chair and Reviewer of IEEE conferences. His research interest includes Machine Learning and Big Data Analytics.

Ajay Kumar Shrivastava is working as Professor in KIET Group of Institutions, Ghaziabad, India. He is having 17 years of teaching and research experience. He completed Ph.D. in Computer Science from Dr. H. S. Gour University, Sagar in the field of Embedded Systems. He did M.C.A from U.T.D Campus, Dr. H. S. Gour University, Sagar (M.P) in 2002. He is a member of various professional societies like IEEE, ACEEE, IACSIT etc. He is a member of the editorial boards of International Journals and Reviewer of the various journals and conferences organized by ACEEE. Email: ajay@kiet.edu

Arun Kumar Tripathi received B.Sc. (Electronics) degree from Dr. H. S. Gour University, Sagar and M.Tech. from Uttar Pradesh Technical University in Computer Science and Engineering. He has completed Ph.D. from National Institute of Technology, Kurukshetra. He joined the KIET Group of Institution, Ghaziabad in 2003 and presently working as Associate Professor. His area of interest is Mobile \& Wireless Communication and Machine Learning. He has published more than 38 papers in various International, National conferences and Journals. He is also reviewer of three SCI Journals. Email: mailtoaruntripathi@gmail.com

Article submitted 2019-06-12. Resubmitted 2019-08-19. Final acceptance 2019-09-08. Final version published as submitted by the authors. 